日消外会誌 34 (12)：1756～1760，2001年

症例報告

\title{
原発性胆囊管癌の 4例
}

函館市医師会病院外科, 北海道大学大学院癌医学専攻癌制御医学講座腫瘍外科学分野*

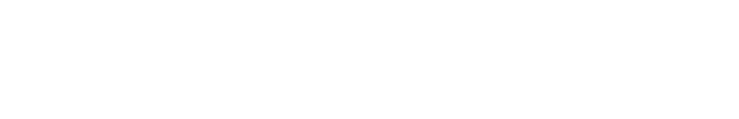

原発性胆囊管癌の4例を経験した . 症例 1 は70歳の男性で, 胆囊結石症の診断で胆囊摘出術を施行 し,切除標本で胆囊管癌と診断され，2期的に胆管切除， $\mathrm{D}_{2}$ 郭清を施行した 組織学的には pat $\mathrm{C}$,tub ${ }_{1}$, $\mathrm{fm}, \mathrm{n}_{1,2}(-)$ で, 術後 9 年目に他病死したが再発はなかった . 症例 2 は61歳の男性で, ERCP で中部 胆管の狭窄を認め, 胆管癌の診断にて肝床, 胆囊, 胆管切除 $\left(\mathrm{D}_{2}\right)$ を施行 . pat $\mathrm{C} B \mathrm{Bm}, \mathrm{tub}_{1}, \mathrm{ss}, \mathrm{n}_{2}$ （+）であった．術後 9 年 4 か月の経過で再発なく生存している．症例 3 は54歳の男性で, 経皮経肝胆 囊造影で胆囊管に不整な途絶を認め, 生検にて胆囊管癌と診断され, 肝床, 胆囊, 胆管切除 $\left(D_{2}\right)$ を 施行した . pat $\underline{C} B m$, tub 2 , ss , $\mathrm{n}_{12}(-)$ であったが , 術後16か月目に癌性胸膜炎のため死亡した . 症例 4 は70歳の女性でCT にて胆囊管腫瘍を認め, 生検で腺癌と診断され, 肝床, 胆囊, 胆管切除 $\left(\mathrm{D}_{2}\right)$ を施行した . pat C , pap , ss, $\mathrm{n}_{12}(-)$ で, 術後 1年の経過で再発なく生存している.

はじめに

原発性胆囊管癌は比較的まれな疾患であり，また， 胆囊管という狭小な部位に発生するため，画像上，胆 囊管の閉塞以外の所見が得にくく，術前に確定診断さ れることは少ない.当院において術前診断が可能で あつた 2例を含め，4例の原発性胆囊管癌を経験した ので，本邦における過去の報告例と合わせ報告する .

症例

症例 $1: 70$ 歳, 男性

右季肋部の腫瘤と腹痛を主訴に来院した . 腹部US と CT 検査で胆囊の腫大, 壁肥厚, 胆石 4 個を認めた が, 腫瘍性病変を認めなかった，腫瘍マーカーCEA， CA 19-9 ,A FP はいずれも正常範囲内であつた .胆囊結 石症の診断にて1989年10月, 胆囊摘出術を施行した . 術中，胆囊管の壁肥厚を認めたが，炎症によるものと 判断した . 切除標本の病理組織学的検討で胆囊管癌と 診断されたため，同年12月，胆管切除， $D_{2}$ 郭清を追加 した .切除標本において胆囊管は $3.0 \mathrm{~cm}$ 長残存し,末梢 側胆囊管に長径 $1.7 \mathrm{~cm}$ 大 , 全周性の結節浸潤型腫瘍を 認めた . 腫瘍の胆管への進展はなかった (Fig. 1) . 胆 道癌取扱い規約に従い病理所見を記載すると, pat C , $\mathrm{tub}_{1}, \mathrm{fm}, \mathrm{n}_{12}(-), \mathrm{y}_{0}, \mathrm{v}_{0}, \mathrm{pn}$ ○であった. 術後 9 年目 に脳梗塞のために死亡したが, 癌の再発所見はなかっ

$<2001$ 年 7 月 30日受理 $>$ 別刷請求先 : 杉浦 博

T 041-8522 函館市富岡町2-10-10 函館市医師会 病院外科
た.

Fig. 1 Macroscopic findings of the resected specimen in case 1 showing a nodular tumor in the cystic duct, measuring $1.7 \mathrm{~cm}$ in size. TM ; tumor, CD ; cy stic duct, CBD ; common bile duct, LHD ; left hepatic duct, RHD ; right hepatic duct.

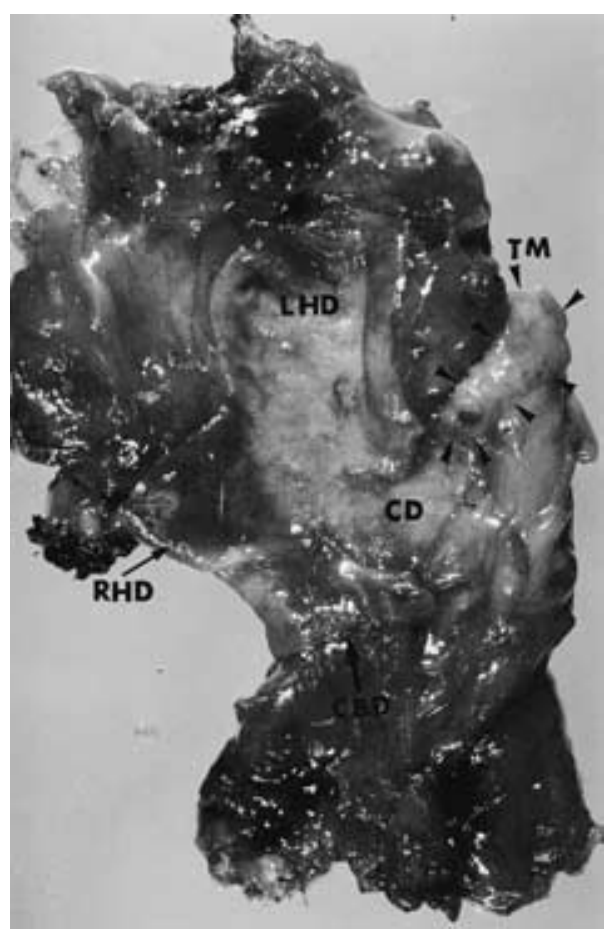


Fig. 2 ERCP in case 2 demonstrated filling defect of the middle bile duct and an obstruction of the cystic duct.

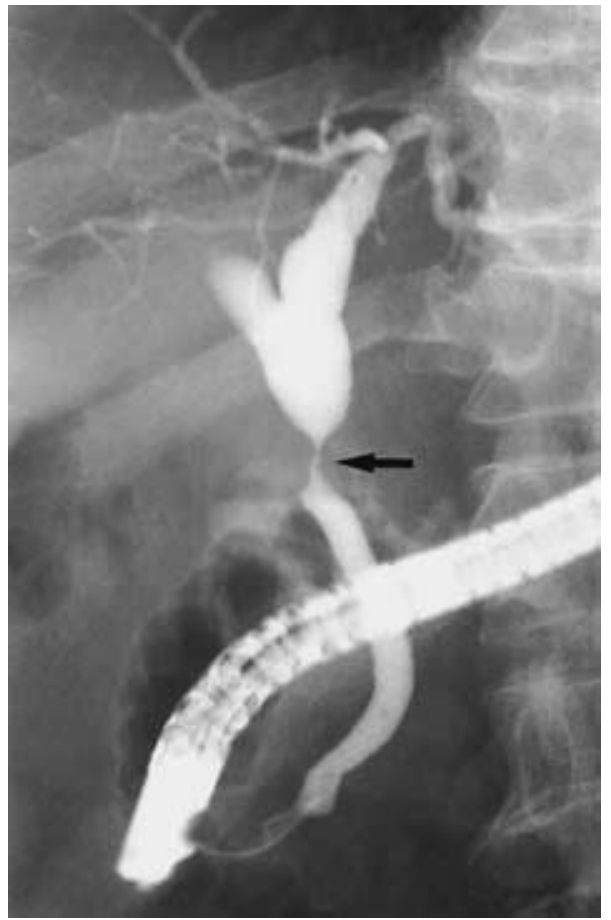

Fig. 3 Microscopic findings of the cystic duct in case 2 show ing papillary grow th of well differentiated tubular adenocarcinoma in the lumen of the duct, and infiltration into the subserosa (Hematoxy lin and eo$\sin ; \times 13.2)$

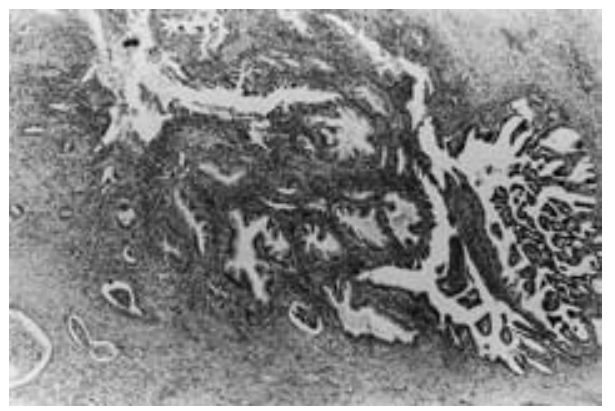

症例 $2: 61$ 歳, 男性

黄疸を主訴に来院した.初診時の血液データでT-Bil が5.0mg/dl , GOT が494IU/ml , GPT が578l U/ml と上 昇し，また ,A LP が1061।U / $l, \gamma-G T P$ が10911U $/ l$,LDH
Fig. 4 ERCP in case 3 showing a filling defect in the cy stic duct.

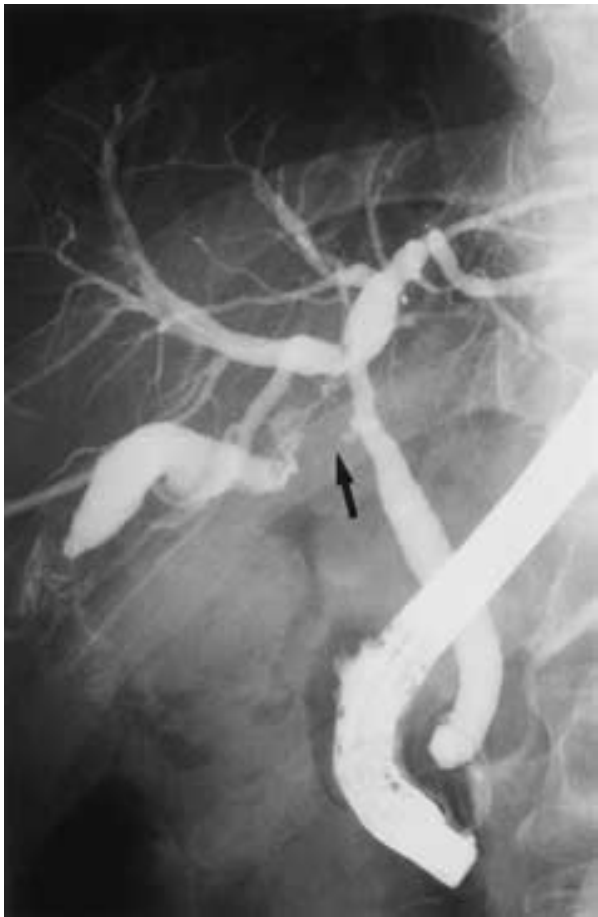

Fig. 5 CT in case 4 showing an enhanced and irregular tumor, measuring $1.7 \mathrm{~cm}$ in size in the cystic duct.

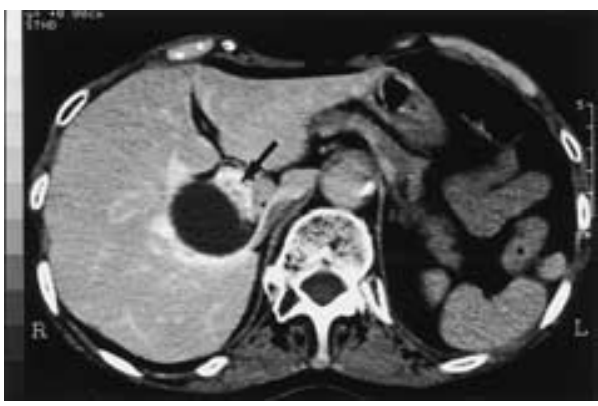

が776IU/ノ と，胆道系酵素が上昇していた．腫瘍マー カーはCA 19-9が231U $/ \mathrm{ml}$ と上昇していた他は， CEA ,A FP ,PIV KA -2は正常範囲内であった .腹部 US では胆囊は萎縮し，内腔に胆囊結石が充満していた． ERCP で中部胆管に狭窄像を認め，胆囊管は造影され なかった (Fig. 2) . 胆管癌の診断にて1992年12月，肝 床, 胆囊 , 胆管切除 $\left(D_{2}\right)$ を施行した . 腫瘍は $2.5 \mathrm{~cm}$ 
Fig. 6 Macroscopic findings of the resected specimen in case 4 showing a papillary tumor in the cystic duct, measuring $1.0 \mathrm{~cm}$ in size. T M ; tumor, GB ; gallbladder, CD ; cystic duct, CBD ; common bile duct, HD ; hepatic duct.

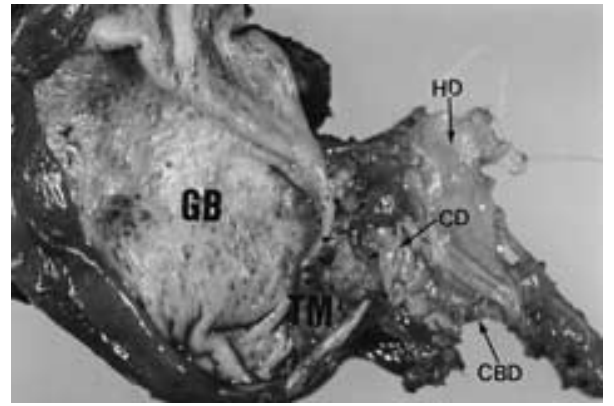

大の結節浸潤型で主座は胆囊管にあり，腫痬により胆 囊管は閉塞し連続性に胆管へ進展していた．組織学的 には高分化型管状腺癌が胆囊管において乳頭状に増生 し内腔をほぼ占拠し，線維筋層を越えて墏膜下にまで 達していた(Fig. 3) .No.13aリンパ節への転移も認め, pat $\underline{C} B m$, tub 1 , ss , $\mathrm{n}_{2}(+)$, $\mathrm{ly}_{2}, \mathrm{v}_{0}, \mathrm{pn}_{1}$ であつた stage III の進行癌であつたが術後 9 年 3 か月が経過し た現在，再発なく生存している．

症例 $3: 54$ 歳, 男性

腹痛を主訴に来院 . 入院時，WBC が12300/ $\mathrm{mm}^{3}$, CRP が1.4mg/dl と上昇していたが,生化学検査所見に 異常はなく，腫瘍マーカーCEA，CA 19-9, DUPA N-2, SPA N-1はいずれも正常範囲内であった .腹部USで胆 囊は緊満し,内腔に多量の胆泥を認め,US ガイド下に
PT GBD を行った . ERCP と PT GBD からの同時造影 で胆囊管に陰影欠損を認めた(Fig.4) .ERCP ガイド下 に生検鉗子を胆囊管内に挿入して生検し，腺癌の診断 を得た . 1997年 5 月，胆囊管癌の診断のもと肝床，胆 囊，胆管切除 $\left(D_{2}\right)$ を施行した . 腫瘍は1.5cm 大の結節 浸潤型で胆管にも進展しており，病理所見は pat $\underline{\mathrm{C}}$ $\mathrm{Bm}, \mathrm{tub}_{2}, \mathrm{ss}, \mathrm{ly}_{1}, \mathrm{v}_{0}, \mathrm{pn}_{1}, \mathrm{n}_{1,2}($ - )であつた . 術後 経過は良好で第30日目に退院したが , 術後 6 か月目に 右胸水が貯留し胸水細胞診で Class V が得られ，また， 胸膜生検で胆囊管癌細胞と同樣な腺癌細胞が採取さ れ, 胆囊管癌の再発と診断した．化学療法を行ったが 効なく術後16か月目に死亡した .

症例 $4: 70$ 歳, 女性

腹痛を主訴に来院した . 11年前に胆囊結石を指摘さ れ，以後，胆囊結石溶解剂を内服していた．初診時， 白血球数 , CRP は正常であつたが, GOT が1147IU $/ l$, GPT が669IU $/ l$ と著明に上昇し，A LP が458IU $/ l ， \gamma$ $\mathrm{GTP}$ が643IU $/ l$, LDH が2296IU $/ l$ と胆道系酵素の上 昇を認めた .また，T-Bil が2.6mg/dl，血清 amylase が3459IU $/ l$ と上昇していた . 腫瘍マーカーCEA，CA 19-9 A F P はいずれも正常範囲内であった . 腹部 US で胆囊は腫大し，内腔に3mm 大の結石を 2 個認め，ま た，胆囊管内に2 $\mathrm{cm}$ 大の腫瘤を認めた.CT 検査で胆囊 管内に造影効果を有する辺縁不整な腫瘤を認めた (Fig.5).ERCP で胆囊管は途絶し，ERCP ガイド下の 胆囊管からの生検で腺癌と診断された．血管造影では 胆囊動脈の encasement と淡い tumor stain を認めた . 胆囊管癌の診断にて2000年 3 月, 肝床, 胆囊 , 胆管切 除 $\left(D_{2}\right)$ を施行した．切除標本で，胆囊頸部近傍の胆

Table 1 Clinicopathologic features of four cases of cystic duct carcinoma

\begin{tabular}{|c|c|c|c|c|c|c|c|}
\hline No & $\begin{array}{l}\text { A ge, } \\
\text { Sex }\end{array}$ & Operation & Histology & Location & Depth & $\begin{array}{l}\text { Lymph node } \\
\text { metastasis }\end{array}$ & Outcome \\
\hline 1 & $70, \mathrm{M}$ & $\begin{array}{l}\text { Cholecy stectomy, and } \\
\text { secondary resection } \\
\text { of bile duct }\end{array}$ & tub 1 & Pat C & $\mathrm{fm}$ & $\mathrm{n} 1,2(-)$ & $\begin{array}{l}9 \text { years, } \\
\text { DOOD }\end{array}$ \\
\hline 2 & $61, M$ & $\begin{array}{l}\text { Extended } \\
\text { cholecystectomy and } \\
\text { resection of bile duct }\end{array}$ & tub 1 & Pat $\underline{\mathrm{C} B m}$ & ss & $\mathrm{n} 2(+)$ & $\begin{array}{l}112 \text { months, } \\
\text { A live }\end{array}$ \\
\hline 3 & $54, M$ & $\begin{array}{l}\text { Extended } \\
\text { cholecystectomy and } \\
\text { resection of bile duct }\end{array}$ & tub 1 & Pat $\underline{\mathrm{C}} B \mathrm{~m}$ & ss & $\mathrm{n} 1,2(-)$ & $\begin{array}{l}16 \text { months, } \\
\text { DOD }\end{array}$ \\
\hline 4 & $70, F$ & $\begin{array}{l}\text { Extended } \\
\text { cholecy stectomy and } \\
\text { resection of bile duct }\end{array}$ & pap & Pat C & ss & $\mathrm{n} 1,2(-)$ & $\begin{array}{l}12 \text { months, } \\
\text { A live }\end{array}$ \\
\hline
\end{tabular}

$M$, male ; $F$, female ; tub 1, well differentiated tubular adenocarcinoma ; tub 2, moderately differentiated tubular adenocarcinoma ; pap, papillary adenocarcinoma ; Pat, pathological ; C, cy stic duct ; Bm, middle bile duct ; fm, fibromuscular layer ; ss, subserosal lay er ; DOOD, dead of other disease ; DOD, dead of disease ; 
囊管に1.0x 0.5cm 大の乳頭膨張型腫瘍を認めた . 腫痬 は胆囊管に限局し，胆囊や胆管への進展はなかった .

(Fig. 6) . 病理所見は pat C ,pap ,ss , ly $y_{1}, \mathrm{v}_{0}, \mathrm{pn}_{0}, \mathrm{n}_{12}$ （－）であった . 術後経過は良好で第30日に退院し，術 後 1 年が経過した現在,再発の所見なく生存中である.

以上 4 症例の臨床，病理組織学的所見をまとめ，一 覧表とした (Table 1)．

\section{考察}

1951年 $\mathrm{F}$ arr $\mathrm{rr}^{1}{ }^{1}$ は胆囊管癌を胆囊，肝管，総胆管のい ずれにも腫瘍がなく，胆囊管に限局しているものと定 義し, 胆囊管癌の報告に際してはこの基準が汎用され てきた．しかし，胆囊管癌は進行すれば胆囊や胆管へ 進展することから，癌巣が胆囊や胆管に広がっていて も胆囊管が原発と考えられる症例は原発性胆囊管癌と して報告されるようになっている．第4 版胆道癌取扱 い規約においても胆囊管にほほ限局する癌腫を胆囊管 癌としている。

本症は比較的まれな疾患であり，醫学中央杂隹誌によ る検索で会議録を除いた本邦の論文報告(59例) 18) で あつた .自験例 4例を含めた63例について検討すると， 男性35例，女性28例で, 男女比は1.3: 1で, 年齢は34 歳から93歳 (65.5 10.0歳) であつた。初発症状を記載 のあつた61例について検討すると，重複を含むが，腹 痛が38例 $(61 \%)$ と最も多く, 次いで黄疸13例 (21 $\%)$ ，腹部腫瘤12例 $(20 \%)$ ，発熱 7 例 (11\%) の順に 多くみられた．胆囊結石の合併は63例中18例 (29\%) で あった . 術前に胆囊管癌あるいは胆囊管腫痬と診断さ れたのは，記載のあった59例中21例（36\%) で，谷の 他は胆囊結石，総胆管結石18例(31\%)，胆管癌，胆管 腫瘍14例 (24\%)，胆囊炎 6例 (10\%) との術前診断で あった . 手術は全身状態の悪い1例を除いた62例に施 行され, うち 3例は癌局所進展のために非切除に終 わった . 切除可能であった59例の術式は, 胆囊摘出兼 胆管切除が40例と最も多く, 胆囊摘出13例, 膵頭十二 指腸切除 5 例, 肝拡大右葉切除 1 例であつた . なお， 術前および術中所見から癌の確診が得られず，2期的 に根治術がなされた症例が10例あつた . 癌の占居が胆 囊管に限局した ,いわゆる F arrar の定義を満たした症 例は63例中35例 $(56 \%)$ で，胆管に進展したもの18 例 $(29 \%)$ ）, 胆囊に進展したもの 5 例 $(8 \%)$ ，胆管と胆 囊の両者に進展したもの 5 例 (8\%) であった . 組織学 的癌深達度は $\mathrm{m}$ にとどまるものが切除59例のうちの 5 例 $(8 \%), \mathrm{fm}(\mathrm{mp})$ が13例 (22\%) , ss が30例 (51 \%), se が 9 例 (15\%) , si が 2 例 (3\%) であった .リ
ンパ節転移を認めたのは記載のあった61例中 ,10例(16 \%)で，1群，2群リンパ節転移が各々5例ずつであつ た 、リンパ節転移のあった10例のうち, 術後 5 年以上 の生存例は自験例の1例のみ (症例 2) であった . 組織 型については記載のあつた57例のうち，管状腺癌が38 例(67\%)で, 乳頭腺癌が17例( $30 \%)$, 腺扁平上皮癌， 未分化癌が各 1例 (2\%) であった．また，組織学的完 全切除がなされたのは切除59例中50例 $(85 \%)$ で, 残 りの 9 例は胆管側断端 $(\mathrm{bm})$ あるいは剥離面 $(\mathrm{em})$ 陽 性のために組織学的非完全切除となっていた .

外科治療成績を切除59例のうち予後の記載のあった 52例を対象にKaplan-Meier 法を用いて検討した．対 象群の術後観察期間は27士 30か月で, 5 年生存率は70.1 \%であった . 組織学的完全切除がなされた45例に限っ てみると，再発をきたしたのは肝転移 2 例 ${ }^{2 / 3)}$ と癌性胸 膜炎 1例 (自験例症例 3) の3 例のみで, 術後26士 30 か月の観察期間で 5 年生存率は $84.7 \%$ と良好であっ た。一方，組織学的に癌遺残を認めた 7 例の 5 年生存 率は25\%で, 完全切除群と比較して統計学的に有意に 予後不良であった (logrank p 值 = 0.010) . 術式別に生 存曲線の比較を行ったが, 非打ち切り例が多いために 有意差検定はできなかった .

癌占居が胆囊管に限局した35例の治療成績について みると，手術は34例に施行され，32例に組織学的完全 切除がなされていた . これら32例は術後26士 31か月の 観察で癌再発例を認めず ,5年生存率は $93.2 \%$ と予後は 極めて良好であった .

以上の文献的考察から，原発性胆囊管癌は外科的に 完全切除されれば，予後は比較的良好な疾患と言える． 兴の要因として, 本症は胆囊管という狭小な部位に発 生するために胆囊管閉塞による症状が早期から出現し やすく, 比較的早期の段階で発見され，手術されるこ とが多いのではないかと推察される.

$$
\text { 文献 }
$$

1) F arrar DT A : Carcinoma of the cystic duct. Br J Surg $39:$ 183-185, 1951

2) 長谷川久美, 植竹宏之, 深山泰永ほか：原発性胆囊 管癌の 1例 .日臨外医会誌 $58: 1348-1353,1997$

3) 古田斗志也, 西原一善 : 原発性胆囊管癌の 1 例 .日 臨外医会誌 58 : 2656-2660, 1997

4) 亀井 明, 猪狩功遺, 佐藤栄一ほか: 術前診断しえ た胆囊管癌の一切除例 . 消画像 $2: 87-92,2000$

5）廣吉基己, 長田 裕, 荻野和功ほか：原発性胆囊管 癌の 1例．日消外会誌 $33: 80-84,2000$

6) 森屋秀樹, 中崎久雄, 石過孝文ほか : 術前診断しえ 
た閉塞性黄疸で発症した原発性胆睘管癌の1例． 胆道 13:437-443, 1999

7) 上田順彦,小西一朗, 広野禎介：胆囊側に表層進展 を伴った原発性胆囊管癌の1例 .胆道 13:108112, 1999

8) 岩本末治,木元正利, 小沼英史ほか : 胆囊管原発早 期癌の 1例. 胆道 $12: 427-431,1998$

9) 玉山隆章,古谷正伸, 浮田雄生ほか : 膵頭部癌に合 併した早期胆囊管癌の 1例 . 胆と脺 19 : 11551159, 1998

10) 清原 薰, 小杉光世,家接健一ほか：腹腔鏡下胆䩧 摘出術にて胆嚢癌と判明した症例の検討. 北陸外 科会誌 $16: 43-49,1997$

11) Shito M, Shintoku J, Miyazaki H. Primary carcinoma of the cystic duct associated with sarcoid reactions : Report of a case. Surg T oday 27 : 1177-1181, 1997

12) 辻 信彦,広橋一裕, 久保正二ほか：原発性胆囊管
癌の1例．日臨外医会誌 $58: 188$-191, 1997

13) 石黑義浩, 後藤秀実, 廣岡芳樹ほか：管腔内超音波 検査法が有用であった胆㯻管癌の1例 . Gastroenterol Endsc 39 : 1608-1613, 1997

14) 町田彰男, 新谷 隆, 平塚研之ほか: 腹腔鏡下胆摘 4 年後にみられた乳頭状胆囊管癌の1例.Prog Dig Endosc 49 : 234—235, 1996

15) Shibata $Y, T$ oy oda $S$ : Carcinoma of the cystic duct protruding into the common bile duct : report of a case. Surg T oday $25:$ 1050-1053, 1995

16) 佐藤貴弘, 井上哲也, 木村寛伸ほか：F arrar の診 断基準を満たす原発性胆囊管癌の1例一無石胆嚢 炎にて発症した胆蓑管癌の1例一.日消外会誌 $28: 1745-1749,1995$

17) 佐藤幸作,管野紀明, 細川正夫ほか：原発性胆䝴管 癌の 1切除例 .北海道外科誌 $38: 293-297,1993$

18) 林 秀樹, 三好弘文, 角田洋三ほか : 胆囊管原発早 期癌の1例．日消外会誌 $26: 2459-2463,1993$

Primary Car cinoma of the Cystic Duct : Report of Four Cases

Hir oshi Sugiura, Hiroshi T akahashi, Eiji Shimozawa, A kira F ukunaga, Ry unosuke Hase and Hiroy uki Katoh * Department of Surgery, Hakodate Medical A ssociation Hospital

*Department of Surgical Oncology, Division of Cancer Medicine, Hokkaido University Graduate School of Medicine

We report her ein four patients with primary carcinoma of the cy stic duct. Case 1 : A 70-y ear-old male underwent a cholecystectomy under the diagnosis of cholecystolithiasis. A histopathological examination revealed a tubular adenocarcinoma infiltrating the fibromuscular layer of the cystic duct. Resection of the bile duct was ther efore performed. Nine y ears after the oper ation, he died as a result of a cer ebral infarction. T he carcinoma did not recur. Case 2 : A 61-y ear-old male presented with jaundice. ERCP demonstrated the stenosis of the middle bile duct and an obstruction of the cystic duct. He underwent an extended cholecy stectomy and resection of the bile duct. A histopathological examination revealed an adenocarcinoma of the cy stic duct, with ductal spread to the bile duct. $\mathrm{He}$ is alive and show s no signs of recurrence 112 months after the operation. Case 3 : A 54-year-old male was admitted with acute cholecy stitis. Percutaneous transhepatic cholangiography showed an obstruction of the cystic duct. A n ERCP-assisted biopsy revealed a tubular adenocarcinoma. He underwent an extended cholecy stectomy and resection of the bile duct. Microscopically, the carcinoma infiltrated the subserosal layer of the cystic duct, with perineural invasion and ductal spread to the bile duct. Sixteen months after the operation, he died of pleuritis carcinomatosis. Case 4: A 70-year-old female presented with abdominal pain. CT demonstrated a tumor of the cystic duct. A n ERCP-assisted biopsy revealed a tubular adenocarcinoma. She underw ent an extended cholecy stectomy and resection of the bile duct and is alive with no signs of recur rence one year after the oper ation.

Key words : carcinoma of cy stic duct, gallbladder

[Jpn J Gastroenterol Surg 34 : 1756-1760, 2001]

Reprint requests : Hir oshi Sugiura Department of Surgery, Hakodate Medical A ssociation Hospital 2-10-10 T omioka-cho, Hakodate, 041-8522 JA PA N 